\title{
Nutritional Properties of the Leaf, Seed and Pericarp of the fruit of four cucurbitaceae Species from South- East Nigeria.
}

\author{
Osuagwu, A. N. and Edeoga, H. O. \\ Department of Plant Science and Biotechnology, Michael Okpara University of Agriculture, Umudike, \\ Umuahia, Abia State P.M.B. 7267
}

\begin{abstract}
The proximate composition of the leaf, seed and pericarp of the following cucurbits: Cucurbita ficifolia, Mormodica charantia,Luffa cylindrica and Trichosanthes cucumerina were investigated. The carbohydrate content ranges from (70.17-97.46\%), crude protein(0.23-0.50\%), crude fiber (12.00-29.50\%), ash(0.03-0.90\%), moisture(0.09-1.00\%), fat(0.006\%). The investigation indicates that the leaf, seed and fruit pericarp of the cucurbits are of nutritive value.
\end{abstract}

Keywords: Proximate analysis, seed, leaf and pericarp of the fruit, cucurbit

\section{Introduction}

The Gourd family(cucurbitaceae) includes hundreds of species of vines, bearing coiled climbling tendrils and some of the most unusual fruit in the world (Heiser ,1979). The four plants investigated belong to this group. Momordica charantia (bitter lemon) is a tropical and subtropic vine of the family cucurbitaceae widely grown in India, South Asia, China, Africa and the Caribbeans. Bitter Lemon has the ability to control diabetes. Momordica charantia can be used to expel intestinal gas, tumors, wound treatment, rheumatism, malaria, vaginal discharge and seeds are used to induce abortion (Sofowora, 2006; Taylor, 2006).

Trichosanthes cucumerina(L) belongs to the family cucubitaceae. It is an herbaceous annual climber with perennial root stock. They have tendril bearing vines that will sprawl if not supported. The young unripe fruit are eaten as vegetables, while matured ripened ones are blended after extractor the seed used to prepare stew and soups (Hson-Mou and Paul-Ru-Hay,1986). The roots which are tuberous and white in colour are usually dug, washed peeled and cut into pieces and dried in the sun use as herbal remedies. They are anthelminthic (Burkill, 1985).

Cucurbita ficifolia (Malabar gourd) belongs to cucurbitaceae family. It is an edible squash gourd grown for its edible seeds, fruits and green (Bisogrin, 2002). The immature fruit is eaten while the matured fruit is sweet and used to make confectionary and beverages and sometimes alcoholic. It is used effectively to treat diabetes due to its high D-chiro-Inositol content(Xia and Wang, 2006).

Luffa cylindrica(smooth luffa) belongs to the family cucurbitaceae. It is use as sponge for washing and scrubbing utensils as well as the human body. The young fruits is eaten fresh or cooked as a vegetable. The fruit pulp is used as emollient in Nigeria (Oyetayo et al., 2007).

Nutrition is the science of food, the nutrients and other substances therein, there action, interaction and balance is related to health and diseases (Clamp, 2007).The determination of plants proximate and nutrient content of edible fruit and vegetables plays a crucial role in assessing their nutritional significance. As various medicinal plant species are also used as food along with their medicinal benefits, evaluating their nutritional significance can help to understand the worth these plant species (Pandey et al.,2006).The proximate composition of parts of plants has been determined by some workers (Aletor et al., 2012; Osuagwu, 2008) and found to be highly nutritive. The phytochemical screening of these cucurbits has been carried out and are found to contain alkaloids, flavonoids, phenols, saponins and tannins (Edeoga et al., 2010). These phytochemicals are of medicinal value. These plants evaluated are designated weeds but have their application in traditional medicine.

This research work investigates the proximate content of the leaves, seeds and fruit pericarp of the cucurbits which are designated as weeds but has their application in traditional medicine in order to determine their nutritional values.

\section{Collection of Plant Materials}

\section{Materials and Method}

The mature plant and fruits of the four species of Mormodica charantia, Luffa cylindrica, Cucurcita ficifolia and Trichosantes cucumerina were collected from different locations within the environs of Michael Okpara University Of Agriculture Umudike, in Abia State. The four plant species were identified by the taxonomy unit of the Department of Plant Science and Biotechnology, Michael Okpara University of Agriculture Umudike, Umuahia, Abia State, Nigeria. The leaves, seeds and fruit pericarps of the plants were used for the investigation. They were oven dried using Selecta model 150-900C oven. The dried plant materials were ground using Thomas 
Willey milling machine into fine powder and store in a clean sample bottle and kept in the laboratory at room temperature. The proximate compositions of the samples were carried using the AOAC (1990) methods.

\section{Proximate Analysis}

The procedure for the determination of the proximate composition of the samples was those of the Association of Official Analytical Chemists (1990).The proximate analysis (moisture, fiber, ash, fats, proteins and carbohydrate) of all the samples were determined. The crude fiber and ash content was determined using the Weende described by AOAC (1990). The fat content of the samples was determined using the ether extraction method by reflux soxhlet method described by AOAC (1990). The crude protein content was determined using the kjeldahl method described by AOAC (1990). The moisture content of each sample was determined using AOAC (1990) method. The carbohydrate content was estimated using Miller and Tobin (1980) method. The total carbohydrate was estimated from the balance after accounting for ash, crude fiber, protein and fats as follows: $\%$ carbohydrate $=100-(\%$ crude protein $+\%$ crude fiber $+\%$ ash $+\%$ fat $)$.

\section{Result}

The percentage proximate content of the leaves, fruit pericarp and seeds Momordica charantia, Trichosantes cucumerina, Cucurbita ficifolia and Luffa cylindrica is shown in tables 1-3.

The percentage carbohydrate content of the seeds of the plant ranged from 70.54-87.2, crude protein 0.23-0.36, crude fiber 12.00-29.00, ash 0.03-0.48, moisture 0.09-0.73, fat, 0.006(Table 1). The highest percentage of carbohydrate were found in T.cucumerina seeds (87.24) followed by M. charantia (82.16) and the lowest in L.cylindrica (70.54). T.cucumerina had the highest amount of crude protein and the least protein content was found in C.ficifolia. Crude fiber content was highest in L.cylindrica (29.00\%) and the least in T.cucumerina. Ash was highest in C.ficifolia $(0.48 \%)$, followed by T.cucumerina and least in M.charantia $(0.03 \%)$, while the seeds of L.cylindrica had the highest moisture content $(0.73 \%)$ and the least was in C.ficifolia $(0.09 \%)$. The fat content of the plants was equal $(0.006 \%)$ (Table 1$)$.

Table 1: Percentage carbohydrate, crude protein, crude fiber, ash, moisture content and fat content of the seeds of Cucurbita ficifolia, Mormodica charantia, Luffa cylindrica and Trichosanthes cucumerina.

\begin{tabular}{lllllll}
\hline Seed & Crude protein & Crude fiber & Carbohydrate & Ash & Moisture & Fat \\
\hline C.ficifolia & 0.23 & 19.50 & 79.78 & O,48 & 0.09 & 0.006 \\
M.charantia & 0.30 & 17.50 & 82.16 & 0.03 & 0.38 & 0.006 \\
T.cucumerina & 0.31 & 12.00 & 87.24 & 0.44 & 0.20 & 0.006 \\
L.cylindrica & 0.36 & 29.00 & 70.54 & 0.15 & 0.73 & 0.006 \\
\hline
\end{tabular}

The percentage carbohydrate content of the leaves of the plant species ranged from 86.09-97.46, crude protein(0.31-0.50), crude fiber (12.00-13.50), ash(0.09-0.44) moisture(0.19-0.43) and fat 0.006(Table 2). L.cylindrica had the highest carbohydrate content $(97.46 \%)$, while the least carbohydrate content was in M.charantia $(86.09 \%)$.The highest amount of crude protein was found in the leaves of T.cucumerina $(0.50 \%)$, followed by C.ficifolia $(0.40 \%)$ and the least was those of L.cylindrica $(0.30 \%)$.M.charantia had the highest amount of crude fiber $(13.50 \%)$ and those of the leaves of the other plants have the same amount of crude fiber (12.00\%). C.ficifolia leaves had the highest ash content (0.44\%) followed by L.cylindrica and the least was in M.charantia. The moisture content of the leaves of T.cucumerina was highest and the leaves of L.cylindrica had the least moisture content. The leaves of all the plant species had equal amount of fat (Table 2).

Table 2: Percentage carbohydrate, crude protein, crude fiber, ash, moisture and fat content of the leaves of C.ficifolia, M.charantia, L.cylindrica and T.cucumerina

\begin{tabular}{|c|c|c|c|c|c|c|}
\hline Leaf & Crude Protein & Crude Fiber & Carbohydrate & Ash & Moisture & Fat \\
\hline C.ficifolia & 0.40 & 12.00 & 87.15 & 0.44 & 0.20 & 0.006 \\
\hline T.cucumerina & 0.50 & 12.00 & 89.21 & 0.20 & 0.43 & 0.006 \\
\hline
\end{tabular}

The carbohydrate content of the fruit pericarp of the plant samples ranged from $70.05-83.68 \%$, crude protein $0.25-0.40 \%$, crude fiber $16.00-29.50 \%$, ash $0.06-0.90 \%$, moisture content $0.34-1.00 \%$ and fat content was $0.006 \%$ in all the plant species (Table 3). This indicates that plant parts had low fat content. The highest carbohydrate content occurred in the fruit pericarp of M.charantia (83.68\%), followed by that of L.cylindrica (71.84\%), while the least amount was in T.cucurmerina(70.05\%).C.ficifolia had the highest crude protein content $(0.40 \%)$ and the pericarp of M.charantia and L.cylindrica had the least crude protein $(0.25 \%)$. The crude fiber content of T.cucumerina pericarp was highest $(29.50 \%)$ and the least crude fiber content was in M.charantia $(16.00 \%)$. The highest ash content of the pericarp of fruits was found in L.cylindrica $(0.90 \%)$, followed by C.ficifolia $(0.42 \%)$ and the least was in M.charantia $(0.06 \%)$. The highest pericarp moisture content of C.ficifolia $(1.00 \%)$, and the least amount was in L.cylindrica $(0.34 \%)$. The fat content of the pericarp of the fruits of the plant species investigated was the same $(0.006)$ (Table 3$)$. 
Nutritional Properties of the Leaf, Seed and Pericarp of the fruit of four cucurbitaceae Species .....

Table 3: Percentage carbohydrate, crude protein, crude fiber, ash, fat and moisture content of the fruit pericarp of C.ficifolia, M.charantia,L.cylindrica and T.cucumerina.

\begin{tabular}{lllllll}
\hline Pericarp of the fruit & $\begin{array}{l}\text { Crude } \\
\text { protein }\end{array}$ & Crude fiber & Carbohydrate $\%$ & Ash\% & Moisture\% \\
& & & & & \\
\hline C.ficifolia & 0.40 & 29.00 & 70.17 & 0.42 & 1.00 & 0.006 \\
M.charantia & 0.25 & 16.00 & 83.68 & 0.06 & 0.38 & 0.006 \\
T.cucumerina & 0.30 & 29.50 & 70.05 & 0.15 & 0.74 & 0.006 \\
L.cylindrica & 0.25 & 27.00 & 71.84 & 0.90 & 0.34 & 0.006 \\
\hline
\end{tabular}

\section{Discussion}

This study reveals that C.ficifolia, M.charantia, T.cucumerina and L.cylindrica contain appreciable amount of nutrients which can contribute to the nutrients and energy requirement of man. The plants contain protein which range from $(0.25-0.50)$. The recommended dietary allowance (RDA) for protein is $56 \mathrm{~g}$ for individual weighing $70 \mathrm{~kg}$ and $46 \mathrm{~g}$ for adult weighing $50 \mathrm{~kg}$; children may consume $2 \mathrm{~kg} /$ day (Jones et al., 1985). Abortifacient protein with ribosome- inhibiting properties has been isolated from several cucurbits ( $\mathrm{Ng} e t$ al., 1991). The abortifacient protein include momorcharin from (Momordica charantia), Luffaculin (from Luffa operculata) and luffin-a and luffin-b (isolated from seeds of Luffa cylindrica), trichosathin (Trichosathin kirilowii), and beta-trichosathin (Trichosanthes cucumerina) have been reported to exhibit antitumor, ribosome inactivating and immunomodulatory properties.(Ng et al., 1991). Trichosathin manifest anti-human immunodeficiency virus activity (McGarth et al., 1989).

The Crude fiber of these plant ranges from (12-29.50\%) which is low. Crude fiber in food or plant is an indication of the level of non-digestible carbohydrate and lignin. Crude fiber enhances digestibility, lowering blood cholesterol and blood sugar. It is known to reduce the risk of disease such as obesity, diabetes, breast cancer and gastro intestinal disorder (Saldanha, 1995).

The carbohydrate content of these cucurbits ranges from (70.17-97.46\%). These plants are good sources of carbohydrate for the body metabolic activities when compared with the recommended dietary allowance (RDA) of 130g (Pamela et al., 2005). The ash ranges of these plants are (0.03-0.48\%). Ash is the inorganic residue remaining after water and organic matter have been removed by heating which provides a measure of total amount of minerals within the food. Minerals are not destroyed by heating and they have a low volatility as compared to other food components (Mishra et al., 2012). Moisture content of these plant ranges from (0.04-1.00). The result shows that their shelf life of this fresh plant is high. Moisture content is among the most vital and mostly used measurement in the processing, preservation and storage of food (Onwuka, 2005).

The crude fat content obtained in these four cucurbits were low and equal $(0.006 \%)$. Lipid provides very good source of energy and aids in transport of fat soluble vitamins (Pamela et al., 2005).

The result obtained in this study show and that C.ficifolia, M.charantia, T.cucumerina and L.cylindrica contains appreciable amount of nutrients which can contribute to the nutrient and energy requirement of man.

\section{References}

[1]. Aletor, O., Oshodi, A.A. and Ipinmoroti, K.(2012). Chemical composition of common leafy vegetables and functional properties of their leaf protein concentrate. Food Chemistry, 78;63-68.

[2]. Association of Official Analytical Chemists (1990). Official Methods of Analysis $12^{\text {th }}$ edn. AOAC Washington, D.C.

[3]. Birognin, D. A. (2002). “Origin and Evolution of Cultivated Cucurbits."Ciencia Rural 32(4):715

[4]. Burkill, H.M. (1984). The Useful Plants of West Tropical Africa. Vol 1. Families A-D. Royal Botanic Garden. Kew.

[5]. Clamp, B. (2007). Overview of nutrition: Module Ohlone College CFS 109, Nutrition.

[6]. Edeoga, H. O., Osuagwu, G. G. E., Omosun G., Mbaebie, B. O. and Osuagwu, A. N. (2010). Pharmaceutical and Therapeutic Potential of some wild Cucurbitaceae species from South- Eastern Nigeria. Recent Research in Science and Technology, 2 (1): 63 -68 .

[7]. Heiser, C.B.(1979). The Gourd Book. A Through and Fascinating Account of Gourds from throughout the world. University of Oklahoma Press, Norman, Oklahoma.

[8]. Hson-Mou, C. and Paul-Ru-Hay, B. (1986). Pharmacology and Application of Chinese Material Medica. Vol.1, World Scientific, Singapore.

[9]. Jones, M. M., Johnson, D.O.,Netlerville, J.T., Wood, J. I. and Joesten, M. D. (1985). Chemistry and Society $5^{\text {th }}$ ed., Saunders College Publisher U.S. A., 521-577.

[10]. Mishra, S. R., Mahunty, M.K., Das, S.P. and Pattanaik, A. K. "Production of Biodisel (methyl ether) from simarouba glauca oil" Res. J. Chem.Sci. 2(5):66-71.

[11]. Ng, T. B., Feng, Z., Li, W.W. and Yeung, H.W. (1991).Improved Isolation and further characterization of beta-trichosathin, a ribosome-inactivating and abortifacient protein from tubers of Trichosanthes cucumerina (Cucurbitaceae).Int. J. Biochem., 23:561567.

[12]. Onwuka, G. I. (2005). Food Analysis and Instrumentation: Theory and Practice. Naphthalic Prints, Surulere, Lagos, Nigeria 219230 .

[13]. Osuagwu, G.G.E.(2008). Protein and vitamin content of four Nigerian Ptercarpus Species. Nigerian Food Journal, Vol 26(1).

[14]. Oyetayo, F.L., Oyetayo, V.O. and Ajewole, V. (2007). Phytochemical Profile and Antibacterial of the seed and leaf of the Luffa plant (Luffa cylindrica). Journal of Pharmacology and Toxicology 2(6):586-589.

[15]. Pamela, C.C., Richard, A. H. and Denise, R. F. (2005). Lippincott illustrated Reviews Biochemistry $3^{\text {rd }}$ ed; Lippincott Williams and Wilkins, Philadelphia, pp. 335-388 
[16]. Pandey, M., Abidi, A. B., and Singh, R.P.(2006). Nutritional Evaluation of leafy vegetable. Paratha J. Hum. Ecol., 19(2):155-156.

[17]. Pearson, D. (1985). Pearson's composition and analysis of food technology. Roland, S. Kirikland ed. (9 th $^{\text {th }}$.). Longman Scientific Publ.pp. 314, 650-657.

[18]. Saldanha, L. G. (1995). Fiber in the diet of United States children results of National Surveys. Pediat.96:994-996.

[19]. Sofowara, A. (2006). Medicinal Plants and Traditional Medicine in Africa. Spectrum Books Ltd Ibadan, Nigeria $2^{\text {nd }}$ edition, pp 151-153, 209-214.

[20]. Taylor, L. (2005). Bitter melon: Herbal Properties and Actions In: The Healing Power of Rainforest Herbs. Raintree Nutrition Inc.SquareonePubl. Inc.New-York, pp 1-5

[21]. Xia, T and Wang, Q. (2006). "D-chiro-inositol found in Cucurbita ficifolia (Cucurbitaceae) fruit extract plays hypo glycaemic role in streptozocin-diabetic rats." The Journal of Pharmacy and Pharmocology 58(1) 1527-32. 